\title{
Analisis Kemampuan Pemecahan Masalah Matematis Siswa SMK Terhadap Pembelajaran Trigonometri Secara Online Berbantuan Android Ditinjau dari Kemandirian Belajar Siswa
}

\author{
Yunita Permata Sari ${ }^{1}$, Kamid $^{2}$, Muhammad Rusdi ${ }^{3}$ \\ 1, 2,3 Program Studi Magister Pendidikan Matematika, Universitas Jambi \\ Jl. Raden Mattaher No.16-Jambi, Kota Jambi, Indonesia \\ permatayunita97@gmail.com
}

\begin{abstract}
The purpose of this study is to describe: (1) To describe students' problem-solving abilities in online learning trigonometry assisted by Android to low independence students at SMK N 2 Tanjung Jabung Timur. (2) Describing students' problem-solving abilities in online learning trigonometry assisted by Android to moderate independence students at SMK N 2 Tanjung Jabung Timur. (3) Describing students' problem-solving skills in online learning trigonometry assisted by Android to high independence students at SMK N 2 Tanjung Jabung Timur. This type of research is qualitative research with a qualitative descriptive approach. The results of the study found that: (1) students of SMK N 2 Tanjung Jabung Timur with the online learning process using the Whatshapp application were not conducive due to various factors that did not support one of them being the child working and going to school, so many children did not understand the learning process carried out by the teacher. existing teacher. (2) when learning trigonometry using the polya model in the problem-solving process, it could be seen that most students cannot draw the information that is given in the given problem. (3) when online learning students' problem-solving abilities can be seen that most students are less active and teachers cannot see students understand or understand the learning given because many are constrained by signals, internet quotas and many children work to meet their needs so that sometimes students are learning online does not follow obtimally.
\end{abstract}

Keywords: Android Assisted Online Learning, Student Independence, Mathematics Problem-solving

\begin{abstract}
Abstrak
Tujuan penelitian ini adalah untuk mendeskripsikan: (1) Mendiskipsikan kemampuan pemecahan masalah siswa pada pembelajaran trigonomtri secara online berbantuan Android pada siswa kemandirian rendah di SMK N 2 Tanjung Jabung Timur. (2) Mendiskipsikan kemampuan pemecahan masalah siswa pada pembelajaran trigonomtri secara online berbantuan Android pada siswa kemandirian sedang di SMK N 2 Tanjung Jabung Timur. (3) Mendiskipsikan kemampuan pemecahan masalah siswa pada pembelajaran trigonomtri secara online berbantuan Android pada siswa kemandirian Tinggi di SMK N 2 Tanjung Jabung Timur. Jenis penelitian ini adalah penelitian kualitatif dengan pendekatan deskriptif kualitatif. Hasil penelitian didapatkan bahwa: (1) siswa SMK N 2 Tanjung Jabung Timur dengan proses pembelajaran melalui daring menggunakan aplikasi Whatshapp kurangnya kondusif dikarnakan berbangai factor yang tidak mendukung salah satunya adalah anak tersebut bekerja dan sekolah (2) pada saat pembelajaran trigonometri dengan menggunakan model polya pada prosses pemecahan masalah dapat dilihat bahwa kebanyakakan siswa tidak dapat menarik informasi yang ada yang dibeikan didalam soal yang diberikan. (3) saat pembelajaran online kemampuan pemecahan masalah siswa dapat dilihat bahwa kebanyakan siswa kurang aktif dan guru tidak dapat melihat siswa mengerti atau paham pembelajaran yang diberikan dikarnakan banyak terkendala dari sinyal, kuota internet.
\end{abstract}

Kata kunci: Pembelajaran Online Berbantuan Android, Kemandirian Siswa, Pemecahan Masalah Matematika

Copyright (c) 2021 Yunita Permata Sari, Kamid, Muhammad Rusdi

$\triangle$ Corresponding author: Yunita Permata Sari

Email Address: permatayunita97@gmail.com (Jl. Raden Mattaher No.16-Jambi, Kota Jambi, Indonesia)

Received 18 Jue 2021, Accepted 27 September 2021, Published 27 December 2021

\section{PENDAHULUAN}

Sejak merebaknya pandemi COVID-19 di Indonesia, banyak cara yang dilakukan pemerintah untuk mencegah penyebarannya, salah satunya dibidang pendidikan. Berdasarkan Surat Edaran Kementrian Pendidikan dan Kebudayaan (Kemendikbud) Direktorat Pendidikan Tinggi No 1 Tahun 
2020 tentang pencegahan penyebaran Corona Virus Disease (COVID-19), pihak Kemendikbud memberikan instruksi kepada seluruh sekolah SD, SMP maupun SMA untuk melakukan pembelajaran online (Kemendikbud, 2020). Menurut (Moore et al., 2011), pembelajaran online merupakan pembelajaran yang menggunakan jaringan internet dengan aksesibilitas, konektivitas, fleksibilitas, dan kemampuan untuk memunculkan berbagai jenis interaksi pembelajaran. Penggunaan teknologi dalam pembelajaran harus dilakukan dengan baik dan terarah agar mampu memberikan kualitas pembelajaran yang baik.

Pembelajaran matematika dengan media pembelajaran berbasis Android dapat digunakan siswa secara mandiri di rumahnya sebagai pendukung pembelajaran di kelas untuk saat ini. Berbagai media dapat digunakan untuk mendukung pelaksanaan pembelajaran, misalnya dapat menggunakan layanan aplikasi pesan instan seperti WhatsApp atau penggunaan video pembelajaran dengan menggunakan Android. Saat mengulas video pembelajaran yang di lakukan dapat menggunakan WhatsApp group, dapat membantu siswa untuk berkomunikasi dalam pembelajaran jarak jauh. (Sidiq, 2019). Namun dalam pelaksanaannya, teknik seperti ini sering dikeluhkan oleh siswa dikarenakan minimnya interaksi dan pendidik cenderung sering memberikan tugas sehingga siswa merasa terbebani oleh tugas-tugas yang diberikan guru (Kusuma \& Hamidah, 2020). Menurut penelitian yang di lakukan oleh Herowati, didapatkan hasil bahwa adanya pengaruh kemandirian pada pembelajaran online.

Menurut Parker, (2005), kemandirian berkaitan dengan bagaimana mengerjakan sesuatu, mencapai sesuatu, dan mengelola sesuatu dengan pikiran diri sendiri. Dengan kemandirian belajar, siswa menggunakan keterampilan untuk merencanakan, mengatur tujuan dan mengontrol kinerja atau belajar, serta konsep diri (Schraw, 2006). Untuk menciptakan siswa yang cerdas dan terampil, tidak hanya dengan belajar tatap muka dikelas tetapi harus di iringi dengan belajar terstruktur dan belajar mandiri (Yamin, 2012). Kemandirian memiliki implikasi penting bagi guru dan siswa, siswa memiliki tanggung jawab atas pengaturan dirinya sendiri selama pembelajaran (Peel, 2020).

Kemandirian belajar memberikan rangsangan diskriminatif untuk menyelesaikan masalah dan meningkatkan akurasi siswa (Mace \& Philip, 2008). Dalam perkembangannya, kemandirian individu dapat ditentukan ketika individu mampu atau tidak dalam memecahkan suatu permasalahan yang dihadapi, termasuk pemecahan masalah matematika. Pemecahan masalah merupakan bagian dari kurikulum matematika yang sangat penting karena dalam proses pembelajaran siswa dimungkinkan memperoleh pengalaman menggunakan pengetahuan serta keterampilan yang sudah dimilikinya untuk diterapkan pada pemecahan masalah yang bersifat tidak rutin (Roebyanto \& Harmini, 2017). Menurut Polya (1978), ada 4 tahapan yang dapat dilakukan oleh siswa untuk memecahkan masalah, yaitu memahami masalah (understanding the problem), merencanakan pemecahan masalah (devising a plan), melaksanakan rencana (carrying out the plan), dan melakukan pengecekan (looking back).

Berdasarkan pemaparan di atas terlihat bahwa kemandirian merupakan suatu hal yang berperan penting dalam pembelajaran khususnya pembelajaran matematika secara online berbantuan Android agar siswa dapat memecahkan permasalahan matematika. Sehingga, peneliti tertarik melakukan 
penelitian ini dengan tujuan untuk menganalisis pembelajaran matematika secara online berbantuan Android di tinjau dari kemandirian siswa, dan mendeskripsikan kemampuan pemecahan masalah siswa pada pembelajaran matematika secara online berbantuan Android di tinjau dari kemandirian siswa

\section{METODE}

Penelitian yang dilaksanakan adalah penelitian kualitatif dengan pendekatan deskriptif kualitatif. Penelitian ini dilaksanakan untuk memperolah gambaran kemandirian siswa dalam pembelajaran matematika yang dilakukan secara online pada masa pandemi sehingga melatih kemampuan siswa dalam memikirkan solusi dari permasalahan yang dihadapi serta tidak harus bergantung pada guru maupun teman. Pembelajaran online yang di lakukan oleh penelitian ini adalah pembelajaran yang dapat diakses menggunakan layanan internet. Penelitian dilaksanakan di SMKN 2 Tanjung Jabung Timur pada semester genap tahun ajaran 2020-2021 pada tanggal 19 April sampai 19 Mei 2021. Pemilihan subjek dalam penelitian ini adalah siswa kelas X sebagai sampel nya. Terdapat 4 subjek pada penelitian ini, yang didapat dari hasil observasi awal berdasarkan kemampuan awal siswa yakni kemampuan tinggi, sedang, dan rendah.

Instrument dalam penelitian ini yakni: (1) lembar observasi untuk mengumpulkan data awal kemampuan siswa dan data keterlaksanaan pembelajaran online berbantuan Android oleh siswa, (2) lembar dokumentasi mengenai kumpulan identitas subjek serta rekaman suara, gambar dan video sebagai bahan evaluasi peneliti, (3) Angket kemandirian siswa pada pembelajaran online berbantuan Android, (4) lembar tes tulis berupa soal essay kemampuan pemecahan masalah siswa (4) pedoman wawancara berupa pertanyaan yang diberikan mengacu pada langkah-langkah pemecahan masalah siswa pada soal tes.

Langkah pertama penelitian ini adalah peneliti melakukan observasi ke SMKN 2 yang berletak di Tanjung Jabung Timur, setelah itu peneliti menyebarkan angket kemandirian ke siswa kelas $\mathrm{X}$ untuk melihat sebatas mana kemandirian yang dilakukan siswa pada pembelajaran di masa pandemik dengan menggunkan android sebagai alat bantu untuk kelancaran proses belajar mengajar. Setalah mendapatkan hasil yang diinginkan, peneliti juga ingin melihat bagaimana proses pembalajaran yang dilakukan menggunakan lembar observasi keterlaksanaan pembelajaran online oleh siswa maupun guru. Kemudian peneliti memperkuat penelitian ini menggunakan instrumen tes pemecahan masalah, kemudian langkah terkahir peneliti melakukan wawancara ke subjek yang telah diteliti.

Analisis data angket kemandirian siswa pada pembelajaran online berbantuan Android menggunakan skala likert dengan 4 pilihan jawaban yakni 1 untuk Tidak Setuju, 2 untuk Sering, 3 untuk Kadang-Kadang, dan 4 untuk Setuju. Hasil pengisian angket disusun dalam bentuk tabulasi dan kemudian dihitung presentasinya. Sedangkan untuk analisis soal tes dilakukan dengan mendeskripsikan kemampuan pemecahan masalah matematis siswa dengan mengikuti langkahlangkah pemecahan masalah Polya, dengan cara mengoreksi hasil tes berdasarkan kunci jawaban serta 
menganalisis dan membuat kesimpulan dari analisis data. Analisis data wawancara dilakukan dengan pemeriksaan kembali hasil wawancara untuk mengurangi kesalahan pada penulisan, sehingga dalam penyajian informasi yang diperoleh dapat digunakan dalam menentukan suatu kesimpulan. Penarikan kesimpulan melalui pencermatan data-data terhadap hasil penafsiran dan evaluasi yang didapat dari hasil wawancara yang dilakukan.

\section{HASIL DAN DISKUSI}

\section{Hasil}

Berdasarkan proses pengumpulan data angket pertama pada tanggal 19 April 2021 didapatkan hasil bahwa:

1. Kelas $\mathrm{X}$ dengan jurusan Teknik Kapal Penangkap Ikan (TKPI) dengan 8 orang siswa di dapatkan bahwa rata-rata persentase kemandirian siswa yakni $17,1 \%$,

2. Kelas X Agribisnis Perikanan Air Tawar (APAT) dengan 12 orang siswa di dapatkan bahwa rata-rata persentase kemandirian siswa yakni $28,6 \%$,

3. Kelas X Otomatisasi dan Tata Kelolah Perkantoran (OTKP) dengan 14 orang siswa didapatkan bahwa rata-rata presentase kemandirian siswa yakni $28,8 \%$,

4. Kelas X Teknik Bisnis Sepeda Motor (TBSM) dengan 15 orang siswa di dapatkan bahwa ratarata presentase kemandirian siswa yakni $25,7 \%$.

Selanjutnya peneliti melihat keterlaksanaan pembelajaran online yang dilaksanakan oleh guru dengan lembar observasi. Pada tahap ini, peneliti melakukan pengamatan secara langsung terhadap aktivitas pembelajaran secara online terhadap sintaks pembelajaran yang guru lakukan, dan didapatkan informasi awal bahwa proses pembelajaran yang dilaksanakan pada masa pandemi di SMKN 2 Tanjung Jabung Timur menggunakan aplikasi Whatsapp, yakni guru membuat Whatsapp group sehingga semua siswa dapat terlibat secara langsung didalamnya. Jika siswa belum memahami materi yang di sampaikan oleh guru, maka guru akan mengirimkan video pembelajaran atau melakukan Whatspps video call dengan para siswa. Berdasarkan hasil observasi, didapat persentase keterlaksanaan pembelajaran yakni sebesar $88,63 \%$.

Berdasarkan persentase kemandirian siswa dan keterlaksanaan pembelajaran oleh guru, terlihat bahwa keduanya memiliki kesinambungan, dimana guru telah mempersiapkan semua bahan ajar yang diperlukan untuk membangun kemandirian siswa dapat dilihat tingginya persentase yang di dapat oleh guru mata pelajaran dan untuk mempermudah siswa memahami materi ajar. Akan tetapi pada pelaksanaannya, terkadang beberapa siswa hanya akan mengisi absensi dan tidak menanggapi guru saat guru menjelaskan materi pada Whatsapp. Hal ini mengindikasikan beberapa siswa memiliki tingkat kemandirian yang rendah saat pembelajaran. Selanjutnya dijelaskan mengenai hasil pengerjaan siswa pada soal tes pemecahan masalah. Jawaban dari subjek pertama yang merupakan siswa kelas X Agribisnis Perikanan air Tawar (APAT) untuk masalah pertama dapat dilihat pada Gambar 1. 


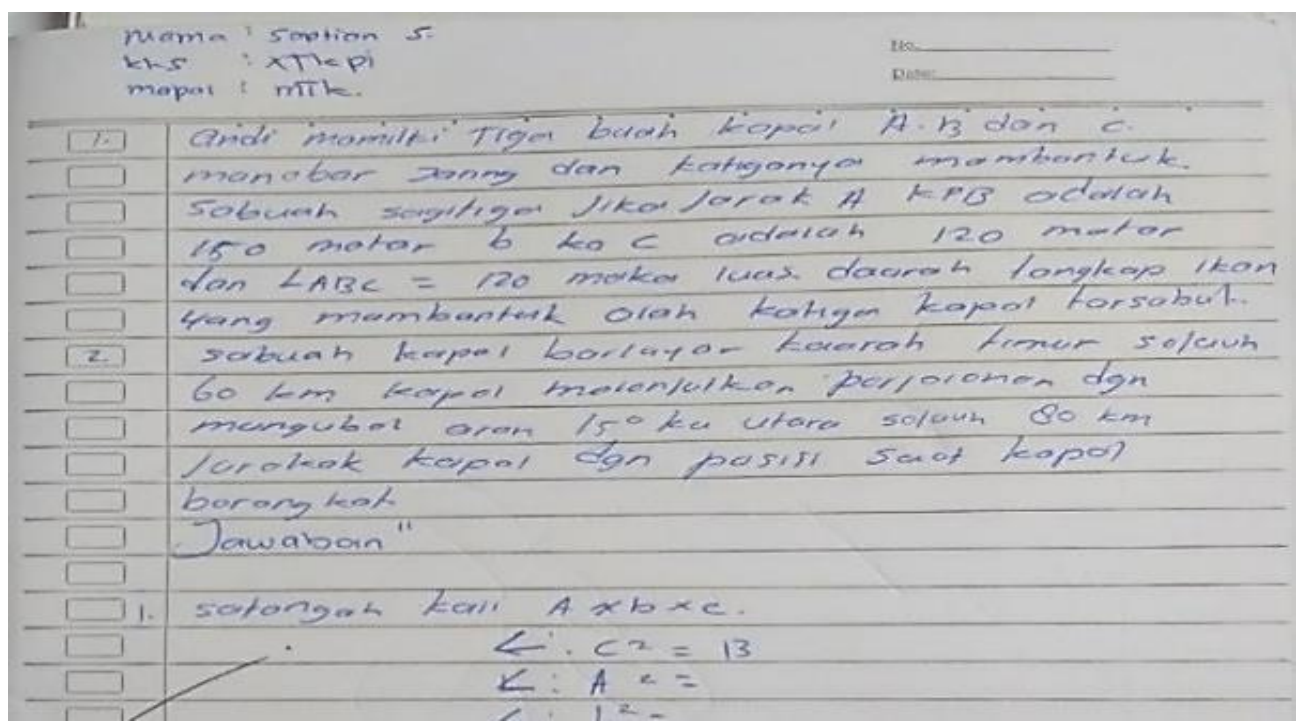

Gambar 1. Jawaban Permasalahan Pertama Subjek Pertama

Pada pelaksanaan pengerjaan soal, subjek 1 merasa bingung dengan apa yang dikerjakan terhadap permasalahan yang diberikan oleh peneliti. Sehingga peneliti memberikan gambaran pada siswa sesuai dengan Gambar 1, namun subjek tetap saja merasa bingung dalam mengerjakan dan menentukan apa saja yang diketahui, ditanya dan dijawab. Subjek mencoba bertanya lagi ke peneliti, namun peneliti berhenti untuk memberikan petunjuk dan meminta siswa secara mandiri mengerjakan soal yang diberikan. Selanjutnya adalah pengerjaan permasalahan kedua oleh subjek pertama dapat dilihat pada Gambar 2.

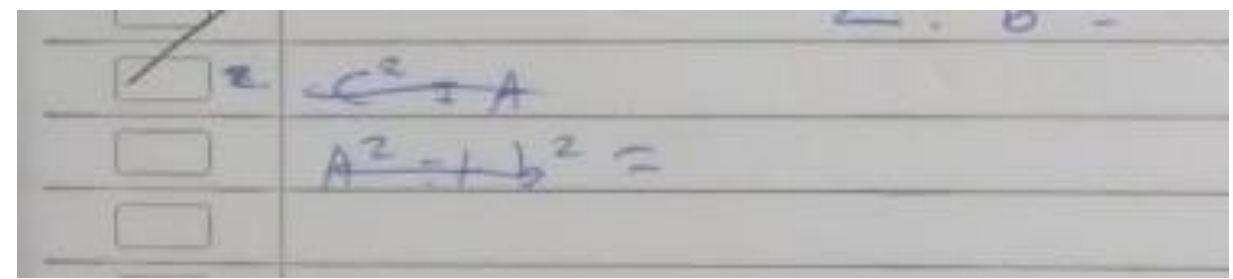

Gambar 2. Jawaban Permasalahan kedua Subjek Pertama

Pada saat pengerjaan soal, subjek belum mampu mengerjakan soal yang ada, dimana siswa belum mampu menyaring informasi, sehingga siswa tidak dapat mengisi soal yang ada yang di berikan oleh peneliti sehingga siswa tidak dapat membrikan jawaban dan tidak dapat mengerjakan soal serta merumuskan dan melaksanakan soal yang diberikan oleh peneliti. Serta memberikan kesimpulan yang ada. Selanjutnya dijelaskan jawaban dari subjek kedua yang merupakan siswa kelas $\mathrm{X}$ dengan jurusan Teknik Kapal Penangkap Ikan (TKPI) untuk masalah pertama dapat dilihat pada Gambar 3. Setelah memperhatikan jawaban subjek kedua pada Gambar 3 dapat diketahui bahwa subjek kedua mampu menganalisis soal yang ada, yakni mampu menuliskan apa yang diketahui dan ditanyakan dari soal. Akan tetapi subjek masih merasa bingung dengan konsep trigonometri. Selanjutnya akan dijelaskan jawaban subjek kedua untuk masalah kedua dapat dilihat pada Gambar 4. 


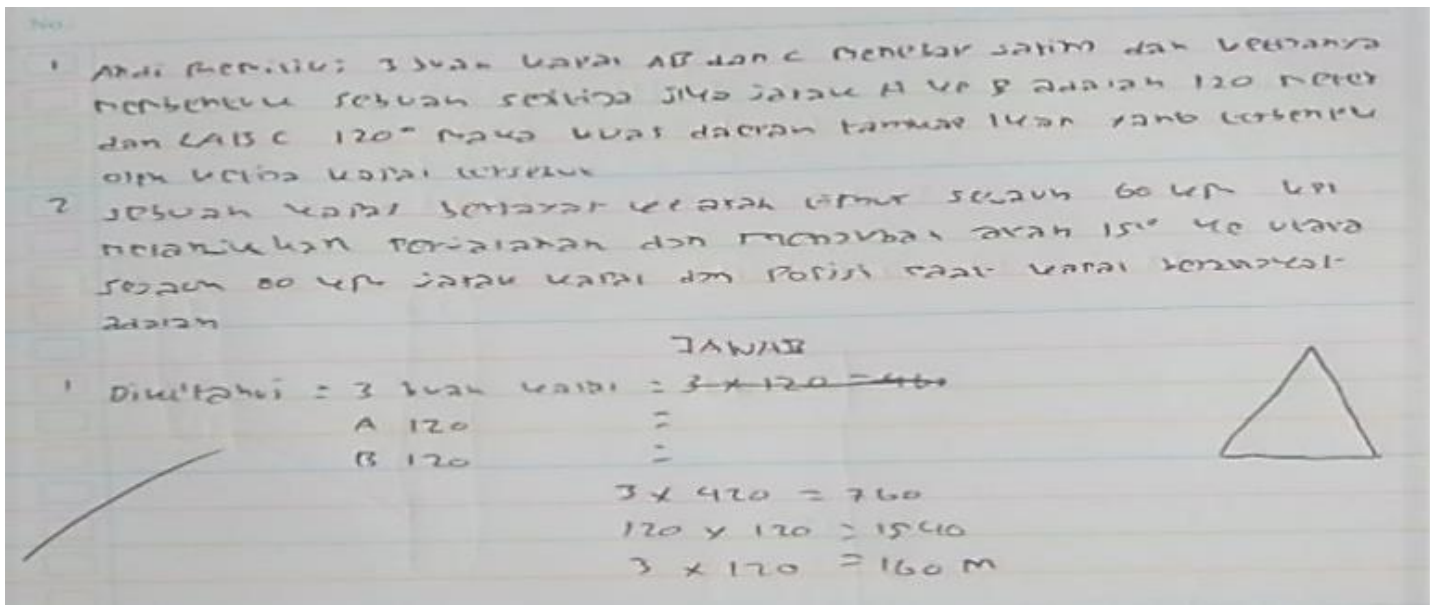

Gambar 3. Jawaban Permasalahan Pertama Subjek Kedua

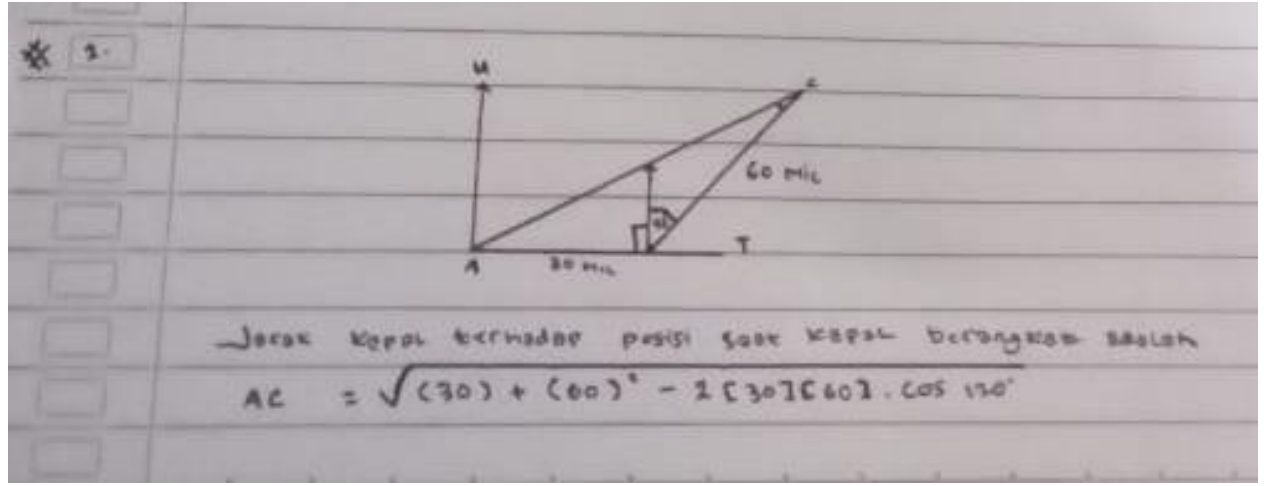

Gambar 4. Jawaban Permasalahan Kedua Subjek Kedua

Setelah memperhatikan jawaban subjek kedua pada Gambar 4 dapat diketahui dapat diketahui bahwa subjek kedua hanya mampu sampai ke peleksanaan dimana hanya mampu merumusakan masalah dan membuat gambar yang ada pada pemecahan masalah trigonomtri namun belum mampu menyelesaikan dengan baik. Selanjutnya akan dijelaskan jawaban dari subjek kedua yang merupakan siswa kelas X dengan jurusan Otomatisasi dan Tata Kelolah Perkantoran (OTKP) untuk masalah pertama dapat dilihat pada Gambar 5.

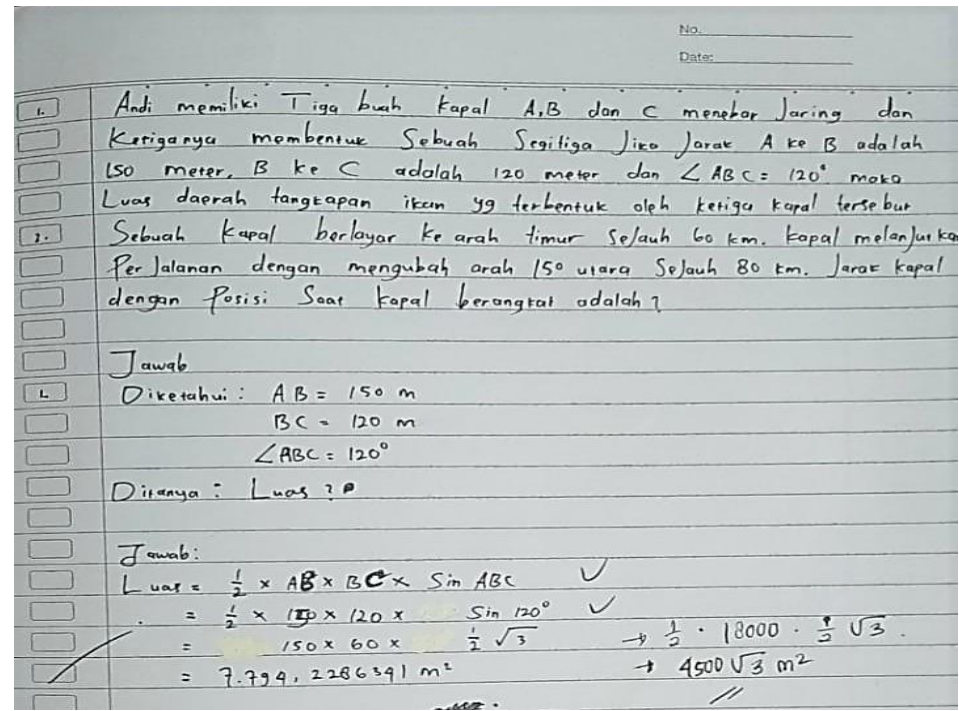

Gambar 5. Jawaban Permasalahan Pertama Subjek Ketiga 
Berdasarkan Gambar 5, terlihat bahwa siswa mampu menyelesaikan soal yang ada, dapat mengetahui apa saja yang diketahui maupun yang ditanyakan pada soal dan memahami konsep apa yang harus digunakan dalam pengerjaan soal. Akan tetapi, terdapat kekeliruan dalam mengerjakan soal dikarenakan siswa kurang hati-hari dalam mengerjakan soal. Selanjutnya adalah pengerjaan permasalahan kedua oleh subjek ketiga dapat dilihat pada Gambar 6.

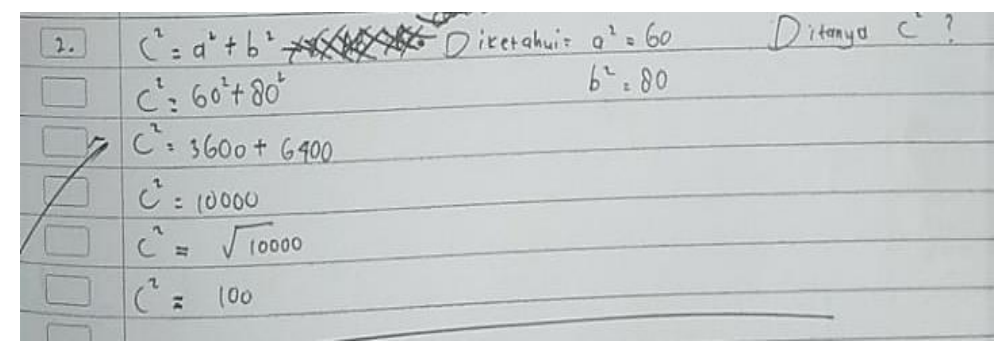

Gambar 6. Jawaban Permasalahan Kedua Subjek Ketiga

Berdasarkan Gambar 6, terlihat bahwa siswa mampu menyelesaikan soal yang ada, dapat mengetahui konsep apa yang digunakan untuk menyelesaikan soal yang diberikan. Namun, terdapat kekeliruan dalam mengerjakan soal sebab pada saat menyelesaikan soal, rumus yang digunakan tidak ditulis secara keseluruan, sehingga jawaban yang didapat kurang tepat. Hasil pengerjaan siswa pada soal tes pemecahan masalah untuk jawaban dari subjek pertama yang merupakan siswa kelas $\mathrm{X}$ Teknik Bisnis Sepeda Motor (TBSM) pada masalah pertama dapat dilihat pada Gambar 7.

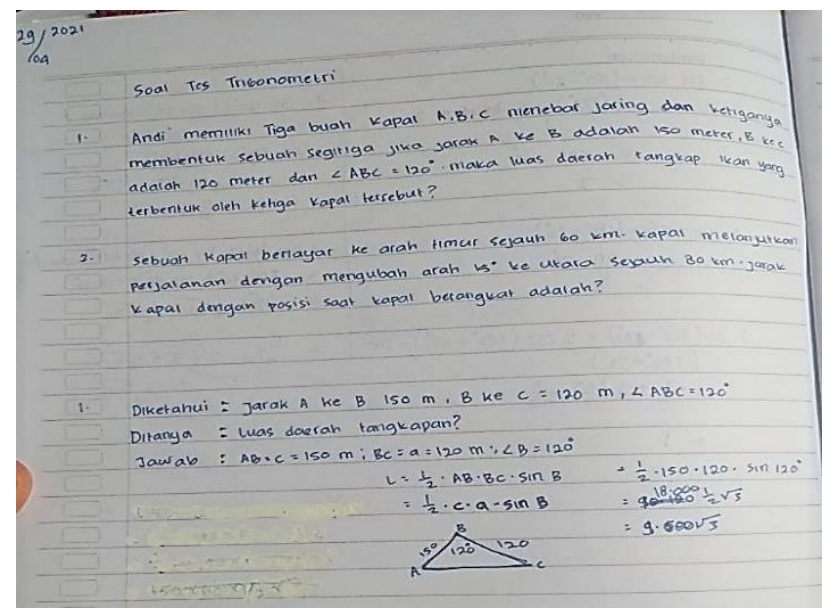

Gambar 7. Jawaban Permasalahan Pertama Subjek Keempat

Berdasarkan Gambar 7 terlihat bahwa subjek mampu mengerjakan soal yang diberikan oleh peneliti, mampu menyaring informasi yang ada dan mampu menuliskan apa saja yang di ketahui dan ditanya. Serta subjek dapat menuliskan konsep mana yang digunakan dan bagaimana langkah-langkah dalam penyelesaian soal yang di berikan. Selanjutnya adalah pengerjaan permasalahan kedua oleh subjek ketiga dapat dilihat pada Gambar 8. 


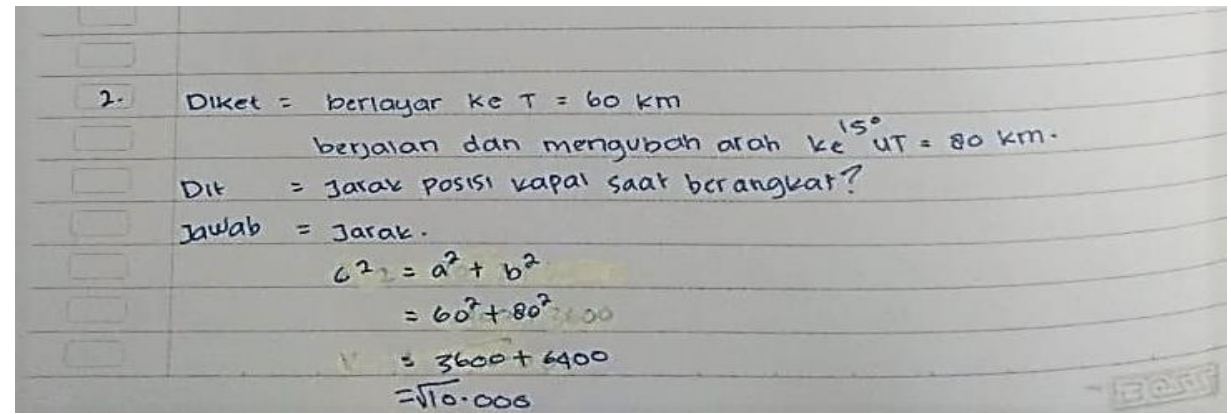

Gambar 8. Jawaban Permasalahan Kedua Subjek Keempat

Berdasarkan Gambar 7 terlihat bahwa subjek mampu mengerjakan soal yang di berikan oleh peneliti, mampu menyaring informasi yang ada dan mampu menuliskan apa saja yang di ketahui dan ditanya. Mengetahui konsep mana yang digunakan dan seperti apa langkah-langkah dalam penyelesaian soal yang diberikan.

\section{Diskusi}

Berdasarkan hasil penelitian yang didapatkan, subjek yang mampu memenuhi indikator kemampuan pemecahan masalah matematis merupakan subjek dengan level kemandirian belajar tinggi. Hal ini sesuai dengan pendapat Assyifa et al., (2020) yakni dalam menyelesaikan masalah, siswa dengan kemandirian tinggi mampu menyelesaikan dengan baik dan sesuai dengan indikator pemecahan masalah. Pernyataan ini sesuai dengan hasil yang didapat yakni seperti pada subjek ketiga dan kempat dimana dimana dari hasil tes kemandirian, subjek berada pada kategori kemadirian belajar tinggi sehingga mampu mengerjakan soal tes dengan baik dan relaif konsisten.

Berdasarkan hasil penelitian, didapat juga subjek yang memiliki kemampuan pemecahan masalah matematis yang rendah memiliki level kemandirian yang rendah. Subjek pertama belum mampu memahami ataupun melaksanakan bahkan merencanakan pengerjaan soal dengan baik dan terstruktur. Subjek pertama juga tidak dapat menyaring informasi yang ada sesuai dengan indikator pemecahan masalah dengan tepat sesuai dengan indikator pemecahan masalah yang ada. Subjek membuat kekeliruan dalam menyaring informasi pada soal dan bingung dan belum mampu menuliskan informasi yang ada didalam soal ke buku latihannya. Selain itu, subjek juga sering bertanya ke peneliti (tidak mandiri) pada saat mengerjakan soal yang berikan.

Pada proses belajar mengajar, sebaiknya siswa diharuskan untuk mandiri dalam keadaan saat ini, dimana siswa harus mampu memanfaatkan teknologi untuk mencari sumber lain guna menambah informasi yang sesuai dengan materi yang diajarkan guru, serta untuk dapat mandiri mengerjakan persoalan yang diberikan. Herowati, (2016) bependapat bahwa kemandirian digunakan dalam kegiatan pembelajaran agar siswa bisa belajar secara mandiri tanpa bergantung pada guru dan siswa lainnya. 


\section{KESIMPULAN}

Berdasarkan hasil penelitian didapatkan bahwa kemandirian siswa dan keterlaksanaan pembelajaran oleh guru memiliki kesinambungan, dimana guru telah mempersiapkan semua bahan ajar yang diperlukan untuk membangun kemandirian siswa dapat dilihat tingginya persentase yang di dapat oleh guru mata pelajaran dan untuk mempermudah siswa memahami materi ajar. Kemudian, siswa yang mampu memenuhi indikator kemampuan pemecahan masalah matematis merupakan siswa dengan level kemandirian belajar tinggi, sedangkan siswa yang tidak mampu memenuhi indikator kemampuan pemecahan masalah matematis merupakan siswa dengan level kemandirian belajar rendah. Hal ini mengindikasikan bahwa guru harus memperhatikan kategori kemandirian siswa agar dapat memperkirakan kemampuan pemecahan masalah yang siswa punya.

\section{UCAPAN TERIMA KASIH}

Peneliti mengucapkan rasa syukur kepada Allah SWT. karena selalu diberikan kelancaran dalam menyelesaikan artikel ini. Peneliti juga mengucapkan terima kasih kepada orangtua dan keluarga yang telah memberi dukungan penuh kepada peneliti. Rasa terima kasih juga peneliti ucapkan kepada pembimbing saya yakni Dr. Drs. Kamid, M.Si.. dan Prof. Dr. M. Rusdi, S.Pd., M.Sc. yang telah memberi bimbingan dan arahan dalam menyelesaikan penelitian dan artikel ini. Terakhir, rasa terima kasih ini peneliti ucapkan kepada sahabat-sahabat saya yang selalu memberi dukungan dan semangat.

\section{REFERENSI}

Ansari, B. I. (2018). Komunikasi Matematik, Strategi Berpikir dan Manajemen Belajar: Konsep Aplikasi. Pena.

Anwar, N \& Riadi, I. (2017). Analisis Investigasi Forensik WhatsApp Messenger Smartphone Terhadap WhatsApp Berbasis Web. 3(1).

Azwar,S. 2002. Tes prestasi: fungsi dan pengembangan pengukuran prestasi. Yogyakarta: Pustaka Pelajar.

Asfah.R, A. A. dan. (2014). Media Pembelajaran. PT Raja Grafindo Persada.

Creswell, J., W. (1998). Qualitative Inquiry And Research Design: Choosing Among Five Traditions. London: SAGE Publications.

Danuri. (2010). Kemandirian Belajar. Sinar Baru.

Darmalaksana, W., Hambali, R. Y. A., Masrur, A., \& M. (2020). Analisis Pembelajaran Online Masa WFH Pandemic Covid-19 sebagai Tantangan Pemimpin Digital Abad 21. Karya Tulis Ilmiah (KTI) Masa Work From Home (WFH) COVID-19. 1-12.

E.F., M. A. dan R. (2016). Desain Pembelajaran Inovatif dari Teori ke Praktek. Raja Grafindo Persada.

F, A. E., Pujiastuti, H., \& Cecep Anwar Hadi. (2020). Analisis Kemampuan Pemecahan Masalah 
Analisis Kemampuan Pemecahan Masalah Matematis Siswa SMK Terhadap Pembelajaran Trigonometri Secara Online

Matematis Ditinjau Dari Kemandirian Belajar Siswa. 1(4), 367-382.

Febriani, P; Widada, W \& Herawaty, D. (2019). Pengaruh Pembelajaran Matematika Realistik Berbasis Etnomatematika terhadap Kemampuan Pemahaman Konsep Matematika Siswa SMA Kota Bengkulu. Jurnal Pendidikan Matematika Raflesia, 04(02). https://ejournal.unib.ac.id/index.php/jpmr.

Helmiati. (2012). Model Pembelajaran. Aswaja Pressindo.

Herowati. (2016). Kemandirian Belajar Siswa Dalam Online Learning di SMKN 1 Sumenep. 6(November), 99-107.

Husna, A. (2018). Analisis Berpikir Pseudo Siswa dalam Memecahkan Masalah Perbandingan Dibedakan Berdasarkan Kemampuan Matematika.

Korucu, A. T., \& Alkan, A. (n.d.). Differences Between M-Learning (Mobile Learning) And Elearning, Basic Terminology And Usage Of M-Learning In Education. 2011. https://doi.org/10.1016/j.sbspro.2020.04.029

Kusuma, \& Hamidah. (2020). Perbandingan Hasil Belajar Matematika dengan Penggunaan Platform Whatsapp Group dan Webinar Zoom dalam Pembelajaran Jarak Jauh pada Masa Pandemik COVID-19. 5(1).

Lestrari, K.E., dan Yudhanegara, M. . (2015). Penelitian Pendidikan Matematika. PT Refika Aditama. M, Y. (2018). Media dan Teknologi Pembelajaran. Teknodika., 13(2).

Mace, FC. Phillip, J. . (2008). Operant Theory and Research on Self-Regulation.

Moore, Deane, D., \& Galyen. (2011). E-Learning, Online Learning, And Distance Learning Environments: Are They The Same? Internet And Higher Educatio. https://doi.org/https://doi.org/10.1016/j.iheduc.2020.10.001

Munawaroh, I. (2019). Penggunaan Media Sosial Sebagai Upaya Meningkatkan Hasil Belajar Matematika Peserta Didik Kelas 9 di SMP N 1 Sindangkasih Kabupaten Ciamis Tahun Pelajaran 2017/2018. 1(9).

Parker. (2005). Menumbuhkan Kemandirian dan Harga Diri Anak. Prestasi Pustaka.

Peel. (2020). Everyday Classroom Teaching practices for Self Regulated Learning. 30(1).

Polya, G. (1978). How to solve it: a new aspect of mathematical method second edition. In The Mathematical Gazette (Vol. 30, p. 181). http://www.jstor.org/stable/3609122?origin=crossref

Polya, G. (2004). How To Solve It:A New Aspect Of Mathematical Method. Pricenton University Press, 53.

Polya George. (1981). Polya Method. 8097.

Ponoharjo. (2017). Metode Penelitian Pendidikan Matematika.

Purbayanti, H. S., \& Oktaviani, D. N. (2019). ANALISIS KEBUTUHAN VIDEO PEMBELAJARAN MATEMATIKA PADA PANDEMI COVID-19. 5, 165-172.

Ratumanan T.G dan Laurens, T.(2003). Evaluasi hasil belajar yang relevan dengan kurikulum berbasis kompetensi YP13IT kerjasama dengan Unipress 
Riyana, C. (2019). Pembelajaran Online. In Universitas Terbuka Tangerang Selatan (1st ed.).

Roebyanto, \& Harmini. (2017). Pemecahan Masalah. PT Ramaja Rosdakarya.

Rusdi, M. (2019). Penelitian Desain dan Pengembangan Kependidikan. PT. Rajagrafindo Persada.

Schraw. (2006). Self Regulated Learning. Intermediate article, Encyclopedia of Cognitive Science.

Sidiq, R. (2019). Pemanfaatan Whatsapp Group dalam Pengimplementasian Nilai-Nilai Karakter Pancasila Pada Era Disrupsi. 4(2).

Subanji. (2013). Proses Berfikir Pseudo siswa dalam menyelesaikan Masalah Proporsi. J-TEQIP, IV(2), 207-226.

Sugiyono. (2012). Penelitian Kuantitatif. Grafindo.

Sulistyani, D., \& Roza, Y. (2020). J urnal Pendidikan Matematika. 11(1), 1-12.

Sumiharsono, R. dan H. H. (2018). Media Pembelajaran (Buku Bacaa). CV. Pustaka Abadi.

Susanto, A. (2013). Teori Belajar dan Pembelajaran di Sekolah Dasar. Kencana.

Vinner, S. (1997). Thought, "The Pseudo-Conceptual and the Pseudo-Analytical Processes in Mathematics Learning. Educational Studies in Mathematics, 34(1-4), 97-129. https://doi.org/10.1023/A.

Waruwu, M. (2020). Studi Evaluatif Implementasi Pembelajaran. 27(2).

Wibawa. (2016). Defragmenting Struktur Berfikir Pseudo dalam memecahkan Masalah matematika. 194.

Widada, W. (2015). Proses Pencapaian Konsep Matematika dengan Memanfaatkan Media Pembelajaran Kontekstual. Jurnal Penelitian Pendidikan Matematika dan Sains. FMIPA Universitas Negeri Surabaya, 22, 31-44.

Yamin. (2012). Desain Baru Pembelajaran Konstruktivistik. Referensi. 